\title{
Amino acid supplements and metabolic health: a potential interplay between intestinal microbiota and systems control
}

\author{
Francesco Bifari ${ }^{1}$, Chiara Ruocco ${ }^{2}$, llaria Decimo ${ }^{3}$, Guido Fumagalli ${ }^{3}$, Alessandra Valerio ${ }^{4}$ and Enzo Nisoli ${ }^{2 *}$ (D
}

\begin{abstract}
Dietary supplementation of essential amino acids (EAAs) has been shown to promote healthspan. EAAs regulate, in fact, glucose and lipid metabolism and energy balance, increase mitochondrial biogenesis, and maintain immune homeostasis. Basic science and epidemiological results indicate that dietary macronutrient composition affects healthspan through multiple and integrated mechanisms, and their effects are closely related to the metabolic status to which they act. In particular, EAA supplementation can trigger different and even opposite effects depending on the catabolic and anabolic states of the organisms. Among others, gut-associated microbial communities (referred to as gut microbiota) emerged as a major regulator of the host metabolism. Diet and host health influence gut microbiota, and composition of gut microbiota, in turn, controls many aspects of host health, including nutrient metabolism, resistance to infection, and immune signals. Altered communication between the innate immune system and the gut microbiota might contribute to complex diseases. Furthermore, gut microbiota and its impact to host health change largely during different life phases such as lactation, weaning, and aging. Here we will review the accumulating body of knowledge on the impact of dietary EAA supplementation on the host metabolic health and healthspan from a holistic perspective. Moreover, we will focus on the current efforts to establish causal relationships among dietary EAAs, gut microbiota, and health during human development.
\end{abstract}

Keywords: Aging, Branched-chain amino acids, Diabetes, Essential amino acids, Gut microbiota, Obesity, Healthspan, Microbes, Short-chain fatty acids, Supplement

\section{Background}

Dietary supplementation with essential (EAAs) and/or branched-chain amino acids (BCAAs) regulates metabolism and energy balance by directly affecting peripheral tissues, such as muscles, adipose tissue, and liver [1]. Moreover, EAA supplementation promotes cardiac and skeletal muscle mitochondrial biogenesis [2-4], prevents oxidative damage [5], enhances muscle protein synthesis and physical endurance [2, 6-9], reduces body weight [10-13], and increases immune function [14, 15]. Altogether, these effects have been shown to improve the healthspan and metabolic health [16]. Notably, the effect of EAAs drastically changes when they act in catabolic or

\footnotetext{
* Correspondence: enzo.nisoli@unimi.it

${ }^{2}$ Center for Study and Research on Obesity, Department of Medical Biotechnology and Translational Medicine, University of Milan, 20129 Milan, Italy

Full list of author information is available at the end of the article
}

anabolic conditions [1]. In catabolic states, EAAs represent mostly energy substrates, while in anabolic conditions EAAs fuel protein synthesis and cell growth. Recently, microbial communities present in the gastrointestinal tract, collectively termed the gut microbiota, have emerged as important regulators of metabolism [17-29] and immune homeostasis [30-41]. The human gut is associated with a diverse microbial community that is composed mainly of bacteria [19], but also includes methanogenic archaea (mainly Methanobrevibacter smithii), viruses (mainly phage), fungi, yeasts, and protozoa [42-45]. Metagenomic sequencing showed that bacterial communities usually consist of hundreds or thousands of bacterial taxa, principally pertaining to two phyla: Firmicutes and Bacteroidetes [19]. This ensemble of organisms has co-evolved with the human host [46] and extends the coding potential of human genome with 500-fold more genes [44, 47]. It has 
an essential role in altering the absorption, metabolite transformations, and energy storage [17, 23, 25, 48].

Comparing germ-free mice with otherwise syngeneic and conventionally raised mice allows understanding that the gut microbiota influences concentrations of the most metabolites detected in plasma [28]. Several of these circulating metabolites, such as bile acids and short-chain fatty acids, regulate function and homeostasis of diverse organs and tissues in a system-controlled manner. Gut microbiota can rapidly respond to large changes in diet [49-57], potentially facilitating the diversity of human dietary lifestyles and contributing to the host metabolic phenotype. Dietary EAAs have been suggested to modulate the intestinal immune system, in addition to their roles as building blocks for protein synthesis, nutrient signals, and modulators of gene expression [58-60]. Furthermore, a BCAA-enriched mixture (BCAAem) has been shown to rejuvenate the agerelated modifications of gut microbiota [60]. In this review we will summarize the effect of dietary EAA supplements, highlighting the potential interactions between EAAs and gut microbiota (Fig. 1).

\section{EAA supplementation affects metabolism and health}

In conditions of dietary nitrogen balance, the adult protein turnover is approximately $250 \mathrm{~g} /$ day [61]. Whole body protein synthesis in humans drastically decreases with age being 10 times less in elderly compared to newborns. Similarly, the protein catabolism also decreases with age. These parameters can largely change in conditions of nutrient deprivation and in disease states, for example, in traumatized or septic subjects [62]. In healthy gut, dietary EAAs are efficiently taken up by different amino-acid transporters in the enterocytes of proximal jejunum [63]. Moreover, EAAs, in particular leucine, have been shown to act as potent nutrient signals. At the molecular level, it has been shown that intracellular leucine concentration can be sensed by the multiprotein complex leucyl-tRNA synthetase $[64,65]$, which activates the mechanistic target of rapamycin (mTOR) kinase. Amino acid-induced mTOR activation regulates protein, lipid, and nucleotide synthesis, as well as inhibits autophagy.

Dietary BCAAem supplementation has been shown to improve motor performance and physical endurance [2]. In adult mice, mTOR signaling activated by BCAAem enhances the mitochondrial biogenesis partly through increasing nitric oxide production [2]. In skeletal muscles of aged rats, BCAAem recovers the reduced basal and postinsulin mTOR and p70S6K activation and the impaired post-insulin Akt activation [66], and improves the ageassociated loss of function and muscle mass [67]. BCAAem has been reported also to increase de novo synthesis of proteins and to reduce the protein breakdown, with rescue of rosuvastatin-induced myopathy [5].

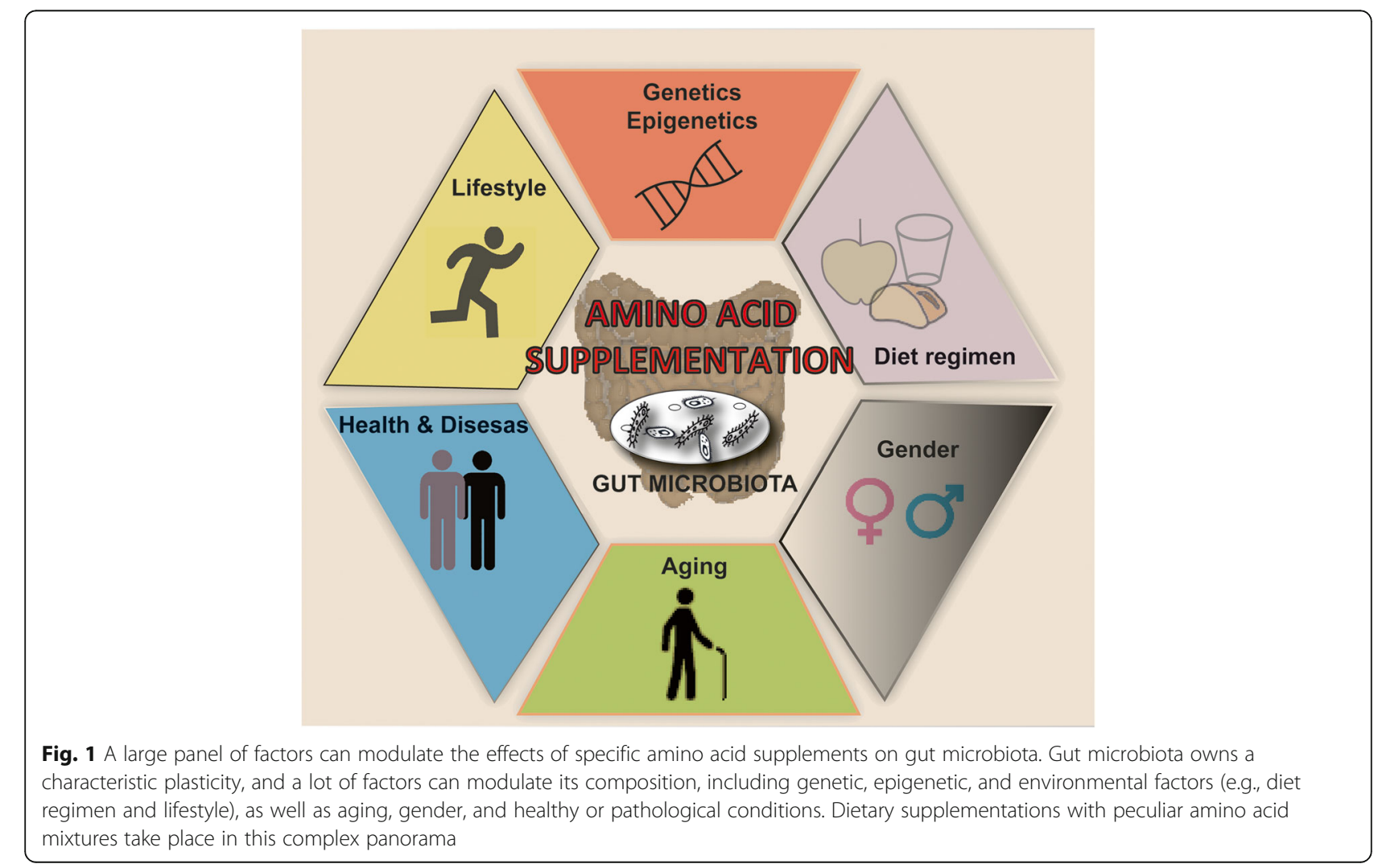


Circulating EAA concentrations are influenced by fasting and pathological conditions [68-71] (Fig. 2). During starvation, EAA metabolism is directed toward oxidation to generate ATP. This process is regulated by activation of AMP-activated kinase (AMPK), a master sensor of the energy balance [72, 73]. BCAA supplementation has been successfully tested in acute and severe catabolic conditions, including burns and trauma [62]. In dialysis patients, the correction of the plasma amino-acid profile, through administration of EAAs, reduces proteinuria and delays the progression of renal disease [74-76]. Moreover, the BCAA supplementation improves prognosis and quality of life in patients with liver cirrhosis $[77,78]$.

Different catabolic states, including starvation and malnutrition, are known to impair immune homeostasis. In particular, the dietary restriction of amino acids impairs cytotoxic $\mathrm{T}$ lymphocytes and natural killer cell function [79], in addition to reduce lymphocyte proliferation [14]. In elderly people, protein malnutrition is one of the major causes of immune dysfunction [80]. Interestingly, dietary supplementation of BCAAs has been reported to reduce the incidence of infections acquired in geriatric long-term rehabilitation centers [15] as well as the risk of bacterial and viral infection in patients with decompensated cirrhosis $[81,82]$. Furthermore, BCAAem supplementation may correct the nephropathy-linked anemia in hemodialysis patients fed low protein diet [83], as well as BCAAs ameliorate the post-intense exercise immunosuppression [14]. In obesity, insulin resistance, and type 2 diabetes mellitus (T2DM), the results of diverse and opposing anabolic and catabolic signals impair amino acid catabolism leading to the BCAA accumulation. Low circulating levels of adiponectin decrease BCAA catabolism through AMPK signal

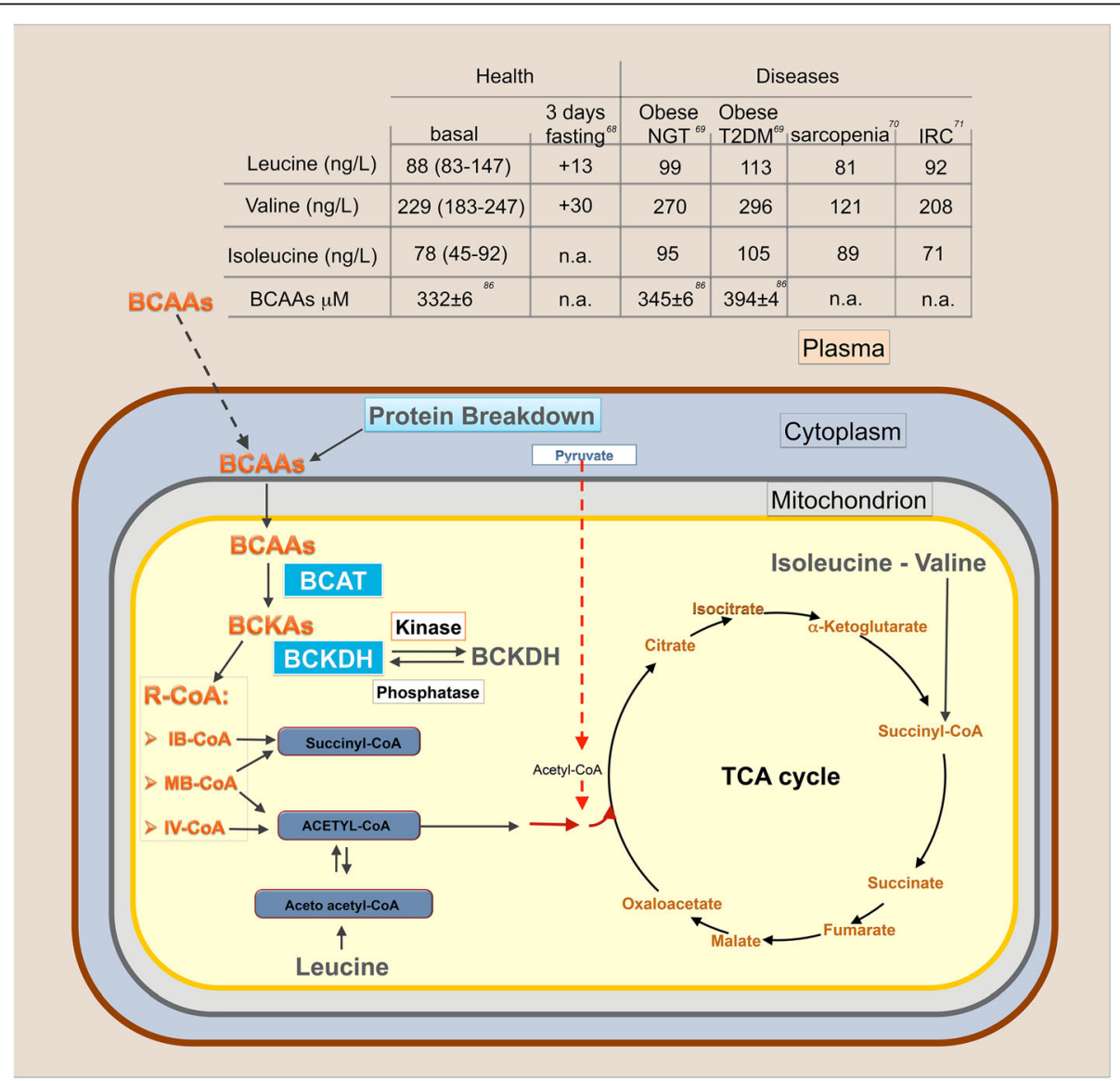

Fig. 2 Biochemistry of BCAAs. Plasma (brown), cytosolic (light blue) and mitochondrial (gray) compartments are depicted. Concentrations of branched-chain amino acids (BCAAs) in physiological and pathological conditions are reported in the table. BCAAs can both enter the cell from the plasma and be produced by protein breakdown. Intracellular BCAAs are transaminated in mitochondria by branched-chain aminotransferase (BCAT). The resulting branched-chain a-keto acids (BCKAs, especially a-keto acid from leucine) inhibit branched-chain a-keto acid dehydrogenase kinase, resulting in elevation of the active state of the rate limiting enzyme branched-chain a-keto acid dehydrogenase complex (BCKDH). BCAAs can be oxidized to generate ATP. Carbon originating from BCAAs enters the tricarboxylic acid (TCA) cycle as acetyl-CoA for complete disposal as $\mathrm{CO}_{2}$. Isoleucine and valine provide carbon for anaplerotic conversion of propionyl-CoA to succinyl-CoA. IB-CoA, isobutyryl-coenzyme A; IV-CoA, isovaleryl-coenzyme A; MB-CoA, a-methylbutyryl-coenzyme A; R-CoA, acyl-coenzyme A 
[84]. Resistin and visfatin, adipokines highly expressed in visceral fat, induce amino acid uptake and protein synthesis. EAAs have been reported to induce mTOR activation and increase insulin receptor substrate-1 (IRS-1) phosphorylation, thereby contributing to the development of impairment of insulin signaling [85]. Indeed, elevated blood BCAA levels have been found in conditions associated with insulin resistance, such as obesity and TDM2 [69, 86-88] (Fig. 2). Moreover, in TDM2 muscles, the BCAA metabolite 3-hydroxyisobutyrate increases endothelial fatty acid transportation, thus worsening the muscle insulin resistance [89]. On the other hand, in selected subsets of obese subjects, BCAA intake is associated with reduced body weight and body fat $[90,91]$. Although the BCAAs have been shown to worsen TDM2 in obese subject, in a long-term randomized study of elderly people with T2DM [92], as well as in patients with chronic viral liver disease [93], BCAA supplementation improved metabolic control and ameliorated insulin resistance. BCAAem-supplemented middle-aged (16 months) mice showed increased expression of peroxisome proliferator-activated receptor $\gamma$ coactivator-1 $\alpha$ (PGC-1 $\alpha)$ and sirtuin 1 (SIRT1) and enhanced mitochondrial biogenesis and function in cardiac and skeletal muscles [2]. Further, BCAAem has been found to improve sarcopenia, that is the age-associated loss of muscle mass and function, in old rats [66] and to prevent muscle atrophy in mice bearing a cachexia-inducing tumor [94]. In middleaged mice, BCAAem preserved muscle fiber size, improved physical endurance and motor coordination [2], decreased protein breakdown and protected against dexamethasone-induced soleus muscle atrophy in rats [8]. When administered orally at the beginning of rat senescence, BCAAem formula has been shown to maintain the health of kidney in aged rats [95], by inducing eNOS and vascular endothelial growth factor expression in kidney, thus increasing vascularization and reducing renal fibrosis. The EAA supplementation can ameliorate myocardial dysfunction in diabetic rats [96]. Moreover, improved vascularization and increased collagen deposition, in addition to the fibroblast proliferation, seem also to be involved in the cutaneous wound healing obtained with topical application of BCAAs and other essential amino acids in aged rats [97].

\section{Gut microbiota affects metabolism and health}

Substantial evidence has been accumulated that gut microbial communities influence feeding, energy homeostasis, endocrine systems, and brain function. The human microbiota produces in gut lumen essential vitamins, including vitamin $\mathrm{K}$, vitamin B12, biotin, folate, thiamine, riboflavin, and pyridoxine, which are absorbed by the intestine $[98,99]$. During the recent years, it has become clear that the influence of the microbiome on health may be even more profound. In particular, it was well established that gut microbiota can generate and indirectly influence the concentration of proteins, including hormones, neurotransmitters, and inflammatory molecules with systemic effects linked to the development of many diseases, such as obesity, T2DM, or atherosclerosis [100-106].

Of particular interest is the bacterial production of short chain fatty acids (SCFAs), e.g., propionate, butyrate, and acetate from polysaccharide degradation, which can be used from the host tissues as substrates for energy metabolism [24]. The abundance in the gut of organisms from Lachnospiraceae family, or the ratio of Firmicutes to Bacteroides are often associated with the production of SCFAs, and their signal to gut enteroendocrine cells is mediated by binding to $\mathrm{G}$ protein-coupled receptors, namely GPR41 and GPR43 [107, 108]. Microbiota-derived butyrate has been reported to regulate levels of glucagonlike peptide 1 (GLP-1), which is produced by enterocytes [109-111]. GLP-1 enhances the glucose-dependent insulin secretion of the pancreatic beta cells [112]. Butyrate has been reported to act as an anti-inflammatory molecule, both on circulating immune cells and enterocytes, thus regulating gut-barrier properties [113-115]. Propionate production seems to be particularly relevant in human health, because it promotes satiety, and prevents the hepatic lipogenesis lowering thus cholesterol production [116-118].

Studies on microbial community structure by $16 \mathrm{~S}$ rRNA gene sequencing have shown that relatively better energy-harvesting bioreactors promote energy storage, increasing the predisposition to obesity $[25,48]$. The high ratio of Firmicutes to Bacteroides, observed in gut microbiota from obese patients, influences degradation of polysaccharides to SCFAs, in particular increasing acetate and decreasing butyrate production [29]. Increasing blood levels of acetate correlate with insulin resistance development, and they increase production of the orexigenic peptide ghrelin in the stomach [119]. Lower butyrate levels are linked to low level inflammation, which in turn decreases insulin resistance [17, 21, 26].

Studies in humans also suggest a role for the gut microbiota in T2DM. In particular, when treatmentnaive patients with metabolic syndrome received intestinal transplantation either from lean donors or from their own feces, recipients of feces from lean donors have a higher abundance of butyrate-producing bacteria linked to improvement of insulin sensitivity [26].

The composition of the gut microbiota is not constant during the lifetime of the host and changes with age [120], owed to several reasons, including alterations in intestinal functions or inflammatory processes [121-126]. Importantly, aging is associated with a shift in the ratio of Bacteroidetes to Firmicutes 
species [125, 127]. Indeed, in people over 60 years the total number of facultative anaerobic microbes (i.e. Firmicutes) increases, while the proportion of Bifidobacteria decreases in comparison to young subjects. The age-related changes of the gut microbiota have been found especially important in pathophysiological processes of the age-related disorders, such as frailty [128], neurodegeneration [129], cognitive decline [130], T2DM [131], and cardiovascular diseases [132, 133].

Different environmental factors can influence gut microbiota composition. Recent study demonstrated that exposure of mice to cold was accompanied to a change in microbiota taxa and caused browning of white adipose tissue, with increase of insulin sensitivity and heat production, in addition to weight loss when compared to control mice. Transplantation of the cold-adapted microbiota from cold exposed mice was sufficient to promote browning of white adipose tissues and to enhance insulin sensitivity in warm recipient mice [134].

Also the diet regimen rapidly and efficiently modifies the relative abundance of specific bacterial taxa [23] and virus [135]. The relevance of this fast, diet-induced dynamics is demonstrated by the microbial changes that are observed over 1-2 days when subjects add dietary fibers to their diet, or consume either a high-fiber and low-fat diet or a low-fiber and high-fat diet for 10 days [49]. From an evolutionary perspective, these changes were selected to maximize energy harvested by food. Indeed, microbiota acts in the intestine as a bioreactor, which permits degradation of otherwise indigestible dietary fibers (i.e., polysaccharides) [24]. Interpersonal variations in the virome are high, even in co-twins and their mothers sharing similar fecal bacterial communities [45]. Dietary intervention is associated with a change in the virome community to a new state, in which individuals on the same diet converged [135]. The functional relevance of this gut virome modification in metabolic health is, however, still unknown.

Modifications of the gut microbial composition affect host metabolism. Colonization of adult germ-free mice with a distal gut microbial community harvested from conventionally raised healthy mice causes a dramatic increase in body fat within 10-14 days, despite an associated decrease in food consumption [25]. Compared with microbiota of lean persons, intestinal microbial composition of obese individuals has less diversity [136], and it is characterized by lower prevalence of Bacteroidetes and a higher prevalence of Firmicutes [137]. Modification of gut microbiota, by either cohousing [138, 139] or antibiotic treatments [140] or transplantation of fecal microbiota from obese versus lean subjects, can modify obesity and metabolic phenotype [25, 27, 141]. These results reveal that transmissible and modifiable interactions between diet and microbiota influence host biology.
Likewise, gut microbiota composition is in turn influenced by a wide range of pathologies (e.g., asthma, arthritis, autism, obesity) [20, 142], and the disease phenotype can be transferred by microbiota transplantation. In fact, recent studies suggest that the microbiome may be a reflection of obesity (or leanness), as well as a cause of it. When obese people are maintained to reduced energy intake with diet and lose weight, the proportion of Bacteroidetes increases relative to Firmicutes. Conversely, when obese people resume their previous food consumption and gain weight, the proportion of Firmicutes increases [100].

In addition to promoting the absorption of monosaccharides from the gut lumen, the microbiota from obese mice selectively suppresses the production of the circulating lipoprotein lipase inhibitor Fiaf (fasting-induced adipose factor/angiopoietin-like protein 4/peroxisome proliferator-activated receptor $\gamma$ angiopoietin-related protein), thus inducing de novo hepatic lipogenesis and deposition of triglycerides in adipocytes and liver [143]. Specific gut bacterial taxa in obese humans and animals metabolize faster phosphatidylcholine to choline, trimethylamine $\mathrm{N}$-oxide (TMAO), and betaine taken with diet. TMAO has been shown to accelerate atherosclerosis by forward cholesterol transport via upregulation of macrophage scavenger receptors [144].

Interactions between the host immune system and gut microbiota prevent the overgrowth of otherwise under-represented or potentially harmful bacteria (for example, pathobionts) $[30,48]$. On the other hand, gut microbiota itself shapes the development of the immune system through a vast range of signaling pathways [38]. Conventional or germ-free housing conditions impact peripheral immune system development in immunocompetent hosts [41].

Dietary fats increase the bile acid taurocholic, therefore altering gut microbiota and promoting colitis in genetically susceptible mouse model [145]. Bacteroides, and in particular Bacteroides fragilis, have been suggested to promote many immune functions of the host. The capsular polysaccharide A (PsA) of Bacteroides fragilis drives differentiation of interleukin-10 (IL-10)-secreting Treg cells. Monocolonization with Bacteroides fragilis, but not with a mutant lacking PsA, stimulates dendritic cell IL-12 production and corrects systemic $\mathrm{T}$ cell deficiencies and Th1/Th2 imbalance [145].

\section{Interaction between amino acid supplementation and gut microbiota}

Given the link between gut microbiome and increasing risk to develop many diseases (e.g. obesity, T2DM, atherosclerosis), the manipulation of the gut microbiota might be a plausible strategy to reduce this risk [146]. Moreover, gut microbiota shows a great plasticity and it 
could be mostly modified by different factors, such as diets or supplements [53].

Dietary proteins and amino acids are important substrates for microbial fermentation in the colon [147], where they also serve as important nitrogen sources for the microbiota and support the growth of microbiota and host [51]. Several research groups have shown that maternal diet affects the colonization of the gut of pups [121], also through epigenetic mechanism [148]. Dietary amino acid intake increases the relative abundance of Bacteroidetes [27, 51]. In particular, supplementation with BCAAem to middle aged mice (15 months) caused a significant reduction in the Firmicutes/Bacteroidetes ratio [60]. Notably, this ratio was comparable to the ratio observed in the 11-month-old mice [60]. In line with these results, BCAAem supplementation significantly changed fructose, sucrose, and oleic acid gut metabolism. Much more information is needed about how the BCAAem supplementation modulates structural and functional properties of gut microbiota, and what is the link with the healthy effects of the BCAAem supplementation as previously described $[1,2]$.

Several common mechanisms are shared by healthy microbiota and dietary EAAs. Essential amino acids can increase the expression of intestinal $\beta$-defensin, the endogenous small cationic polypeptide that functions as a broad-spectrum antimicrobial substance, and thus potentially the amino acids greatly affect the gut microbial community composition [58, 59]. Furthermore, both EAAs and microbiota-derived SCFAs modulate the overall lipid balance and glucose metabolism [1, 18]. Similarly, oral administration of BCAAs or the microbiota-derived butyrate induce a dosedependent increase in GLP-1 release from enterocyte $[110,149,150]$, and decrease the expression of genes involved in the intestinal fatty acid transport and lipogenesis (i.e., acetyl-CoA carboxylase and fatty acid synthase). EAAs may also modify the abundance of gut metabolites by influencing cholecystokinin production and gallbladder contraction [151]. On the other hand, the intestinal dysbiosis alters gut barrier properties and, thus, it may reduce the diet-induced healthy effect [152].

Another point yet to be clarified is whether the supplementation of specific amino acid mixtures is able to modify metabolic diseases, including obesity and T2DM, via gut microbiota modifications, and how this effect can be permanent. The plasma concentration of some EAAs, including BCAAs, is higher in obese T2DM patients than healthy subjects [87]. Obese T2DM patients have also a peculiar gut microbiota composition [25]. In particular, the depletion of species from the Bacteroides genus in obese individuals is related to higher plasma concentration of BCAAs [153]. Of particular interest is the possibility that a subset of gut microbial communities directly synthetized EAAs by themselves, EAAs that would be subsequently absorbed by the intestinal mucosa. Many components of the gut microbiota possess the enzyme to directly synthetize essential amino acids [154, 155]. Indeed, the gut microbiota from obese subject synthetizes BCAAs, while it strongly decreases BCAA catabolism [153]. Thus, the plasma EAA concentrations may be not entirely the consequence of oral EAA intake. On the other hand, oral EAA administration may modify gut microbiota and, consequently, modify (i.e., reduce) paradoxically the plasma EAA concentrations.

Human body metabolism is the result of complex interactions between genetic, epigenetic, and environmental (primarily dietary and lifestyle) factors [156, 157]. Gut microbiota controls metabolism through physiologically important biochemical circuits, which are parts of energy consumption, storage, and distribution [124]. Gut microbiota plays key roles in controlling body metabolism, resistance to infections, and inflammation, as well as preventing autoimmunity disorders and cancer [18, 20, 38]. Brain-gut axis represents an important communication system that regulates whole body energy balance. Information exchange between gut and brain is essential for mammals to adapt to changing environments [38, 158]. EAA supplementation has been shown to improve the health span and metabolic health [16], by reducing body weight [159], increasing immune homeostasis [14, 15], promoting mitochondrial biogenesis [2-4], preventing oxidative damage [5], and enhancing muscle protein synthesis and physical endurance $[2,6-9]$.

Many aspects of amino acid effects on gut microbiota remain to be addressed, for example, whether the different effects of EAAs, acting either in catabolic or anabolic conditions, may be partially attributed to differences of the gut microbiota composition in these metabolic conditions. Moreover, whether EAAs through gut microbiota play some roles in human development, a number of hypotheses about microbial contributions to human development have been proposed in the past decade. One hypothesis is that maternal microbial ecology affects pregnancy, fetal development, and the future health of offspring [121]. Maternal vaginal, gut, and oral microbiota have relevant impact on fetal nutrition and development [121]. Alterations of maternal microbiota are thought to contribute to gestational adverse events, such as the preterm delivery. A compelling question is whether EAA supplements may favorably change the properties of the vaginal and gut microbes before, during, and after pregnancy. A recent study has shown that microbial community structure and function expand and diversify in all body sites from birth to age 4-6 weeks, and it then resembles microbiota from the corresponding maternal body site [160]. A related question is whether microbes associated with breast milk, 
which are highly personalized assemblages [161] and colonize the infant colon, such as some anaerobic species (Bifidobacterium), may be modified by maternal supplementation with EAAs. For example, specific EAA formulas might support growth of bifidobacterial subspecies important for infant gut barrier development and function [162], improved vaccine responses, such as the Bifidobacterium longum subsp. Infantis [163], or production of essential nutrients, including folate and riboflavin [164]. Completely undefined in infant development is the role of father's microbiota and its changes, potentially induced by diet and dietary supplements.

Little is known about the influence of gender on gut microbiota composition, and how this factor can affect the efficacy of amino acid supplements [57, 120]. Few studies have been conducted to investigate the role that sex plays in development and age-related changes of microbiota composition, increasingly evident starting at puberty and most defined in adult and aged subjects [165]. It seems that males and females are uniquely susceptible to factors that shape the microbiota after birth. Male microbiota, in fact, provides testosteronedependent protection from T1DM in a model of nonobese diabetic mice [166].

Several findings suggest bidirectional communication between the gut and the brain in behavioral, psychiatric, and neurodegenerative disorders. The microbiota regulates, in fact, expression of the 5-hydroxytryptamine receptor $\left(5-\mathrm{HT}_{1 \mathrm{~A}}\right)$, brain-derived neurotropic factor (BDNF), and NMDA receptor subunit 2 (NR2A) [167-169]. Thus, anxiety, hyperactivity, depression, nociception, and autism spectrum disorder are among the other psychiatric disorders to be linked to intestinal microbial communities [170-172]. Although the BCAAs do not act as direct precursors for neurotransmitters, they can affect transport of large neutral amino acids (LNAAs), including the BCAAs, across the blood-brain barrier, and thereby influence CNS concentrations of diverse neurotransmitters [173]. BCAAs can also be catalyzed in the astrocyte to produce glutamate and branched-chain $\alpha$-keto acids, which are further taken up by neurons [174]. With the aim to reduce brain tyrosine uptake, BCAAs were given to bipolar subjects during periods of mania [175]. Sixty grams BCAAs were administered daily for 7 days and produced a significant reduction in manic symptoms, consistent with an effect on brain catecholamine. Gut microbiota might be hypothesized to play some role in this effect.

The gut microbes have recently been reported to promote $\alpha$-synuclein pathology, neuroinflammation, and characteristic motor symptoms in a validated mouse model of Parkinson disease (PD). Notably, fecal microbes from PD patients impair motor function significantly more than microbiota from healthy controls when transplanted into mice [176]. Analogously, specific microbe ensembles influence stroke recovery in mice $[177,178]$, and amino acid supplements may potentiate this effect.

Although a body of knowledge is accumulating that suggests potential interactions between EAAs and gut microbiota and their effects on metabolic health and health span, the complex interplay between dietary amino acids and intestinal microbes remains largely unknown. In particular, it remains to be addressed whether the different effects of EAAs, acting either in catabolic or anabolic conditions, may be partially attributed also to differences in gut microbiota composition in these metabolic conditions. Furthermore, based on the current knowledge, the effects and metabolic fate of the dietary EAAs can be largely modified by different gut microbiota ensembles. Both EAA diet supplementation and gut microbiota contribute to human health acting at a systemic level. The precise interplay and the nature of their interactions are still poorly understood and they may help to predict more accurately the therapeutic effect of nutraceutical interventions with specific amino acid formulas.

\section{Conclusions and future perspectives}

Studies of the human gut microbiota have changed how researchers view the pathophysiology of widely diffused metabolic disorders, particularly those linked to age. Humans co-evolved with a web of thousands of microbes, including not only bacteria, but also viruses, fungi and unicellular organisms called Archaea, with which strict relationship exists. Human intestine provides a comfortable environment and nutrients for microbes, and they digest food for us; in addition, they keep away pathogen microbes, synthesize vitamins, organize immune function, and transfer important messages to brain. Thus, it is possible that metabolic problems in humans could be managed with adequate care of the gut microbiota. Since the disturbance of microbial ecology and eco-systems are crucial for physiology in different human life periods, the knowledge of diet and dietary supplement impact on the gut microbiota might be very important for health. Dietary fibers and prebiotics-i.e., substances that induce the growth or activity of microorganisms contributing to the wellbeing of their host-are known to influence health in children and adults. We hypothesize that specific amino acid mixtures are likely to be of benefit to people who follow a typical Western-style diet, in addition to dietary fiber and prebiotics. A deeper understanding of the efficacy of such dietary supplements to maintain gut microbiota has the potential to contribute important therapeutic tools in human metabolic health and weight control.

\section{Abbreviations}

5-HT 1A: 5-Hydroxytryptamine receptor 1A; AKT: Serine-threonine protein kinase; AMPK: 5' Adenosine monophosphate-activated protein kinase; 
BCAAem: BCAA-enriched mixture; BCAAs: Branched-chain amino acids; BDNF: Brain-derived growth factor; EAAs: Essential amino acids; GLP1: Glucagon-like peptide 1; GPR41: G protein-coupled receptor 41; GPR43: G protein-coupled receptor 43; IL: Interleukin 10; LNAAs: Large neutral amino acids; mTOR: Mechanistic target of rapamycin; NR2A: N-methyl-D-aspartate receptor subunit 2; PD: Parkinson disease; PsA: Polysaccharide A;

rRNA: Ribosomal ribonucleic acid; SCFAs: Short-chain fatty acids; T2DM: Type

2 diabetes mellitus; TMAO: Trimethylamine N-oxide; Treg: Regulatory T cell

\section{Acknowledgements}

Not applicable.

\section{Funding}

This study was supported by the Cariplo Foundation, Italy [grant no. 2013-0786 and 2016-1006]. The funding body has not had any role in the design of the study and collection, analysis, and interpretation of data.

\section{Availability of data and materials}

Not applicable.

\section{Authors' contributions}

All authors contributed to article writing and revision. All authors read and approved the final manuscript.

\section{Ethics approval and consent to participate}

Not applicable.

\section{Consent for publication}

Not applicable.

\section{Competing interests}

The authors declare that they have no competing interests.

\section{Publisher's Note}

Springer Nature remains neutral with regard to jurisdictional claims in published maps and institutional affiliations.

\section{Author details}

${ }^{1}$ Laboratory of Cell Metabolism and Regenerative Medicine, Department of Medical Biotechnology and Translational Medicine, University of Milan, Milan, Italy. ${ }^{2}$ Center for Study and Research on Obesity, Department of Medical Biotechnology and Translational Medicine, University of Milan, 20129 Milan, Italy. ${ }^{3}$ Section of Pharmacology, Department of Diagnostics and Public Health, University of Verona, Verona, Italy. ${ }^{4}$ Department of Molecular and Translational Medicine, University of Brescia, Brescia, Italy.

Received: 13 April 2017 Accepted: 17 August 2017

Published online: 04 October 2017

\section{References}

1. Bifari F, Nisoli E. Branched-chain amino acids differently modulate catabolic and anabolic states in mammals: a pharmacological point of view. $\mathrm{Br} \mathrm{J}$ Pharmacol. 2017;174(11):1366-77.

2. D'Antona G, Ragni M, Cardile A, Tedesco L, Dossena M, Bruttini F, Caliaro F, Corsetti G, Bottinelli R, Carruba MO, et al. Branched-chain amino acid supplementation promotes survival and supports cardiac and skeletal muscle mitochondrial biogenesis in middle-aged mice. Cell Metab. 2010;12(4):362-72

3. Valerio A, D'Antona G, Nisoli E. Branched-chain amino acids, mitochondrial biogenesis, and healthspan: an evolutionary perspective. Aging (Albany NY). 2011;3(5):464-78.

4. Nisoli E, Cozzi V, Carruba MO. Amino acids and mitochondrial biogenesis. Am J Cardiol. 2008:101(11A):22E-5E

5. D'Antona G, Tedesco L, Ruocco C, Corsetti G, Ragni M, Fossati A, Saba E, Fenaroli F, Montinaro M, Carruba MO, et al. A Peculiar Formula of Essential Amino Acids Prevents Rosuvastatin Myopathy in Mice. Antioxid Redox Signal. 2016;25(11):595-608.

6. Corsetti G, Pasini E, D'Antona G, Nisoli E, Flati V, Assanelli D, Dioguardi FS, Bianchi R. Morphometric changes induced by amino acid supplementation in skeletal and cardiac muscles of old mice. Am J Cardiol. 2008;101(11A):26E-34E.
7. Nisoli E, Grange RW, D'Antona G. Nutrients and muscle disease. Biomed Res Int. 2015:2015:809830

8. Yamamoto D, Maki T, Herningtyas EH, Ikeshita N, Shibahara H, Sugiyama Y, Nakanishi S, lida K, Iguchi G, Takahashi Y, et al. Branched-chain amino acids protect against dexamethasone-induced soleus muscle atrophy in rats. Muscle Nerve. 2010;41(6):819-27.

9. Xu ZR, Tan ZJ, Zhang Q, Gui QF, Yang YM. The effectiveness of leucine on muscle protein synthesis, lean body mass and leg lean mass accretion in older people: a systematic review and meta-analysis. $\mathrm{Br} J$ Nutr. 2015;113(1):25-34

10. Zhang Y, Guo K, LeBlanc RE, Loh D, Schwartz GJ, Yu YH. Increasing dietary leucine intake reduces diet-induced obesity and improves glucose and cholesterol metabolism in mice via multimechanisms. Diabetes. 2007;56(6):1647-54.

11. Arakawa M, Masaki T, Nishimura J, Seike M, Yoshimatsu $H$. The effects of branched-chain amino acid granules on the accumulation of tissue triglycerides and uncoupling proteins in diet-induced obese mice. Endocr J. 2011;58(3):161-70.

12. Freudenberg A, Petzke KJ, Klaus S. Comparison of high-protein diets and leucine supplementation in the prevention of metabolic syndrome and related disorders in mice. J Nutr Biochem. 2012;23(11):1524-30.

13. Cota D, Proulx K, Smith KA, Kozma SC, Thomas G, Woods SC, Seeley RJ. Hypothalamic mTOR signaling regulates food intake. Science. 2006; 312(5775):927-30

14. Bassit RA, Sawada LA, Bacurau RF, Navarro F, Martins E Jr, Santos RV, Caperuto EC, Rogeri P, Costa Rosa LF. Branched-chain amino acid supplementation and the immune response of long-distance athletes. Nutrition. 2002;18(5):376-9.

15. Aquilani R, Zuccarelli GC, Dioguardi FS, Baiardi P, Frustaglia A, Rutili C, Comi E, Catani M, ladarola P, Viglio S, et al. Effects of oral amino acid supplementation on long-term-care-acquired infections in elderly patients. Arch Gerontol Geriatr. 2011;52(3):e123-8.

16. Nisoli $\mathrm{E}$, Valerio A. Healthspan and longevity in mammals: a family game for cellular organelles? Curr Pharm Des. 2014;20(35):5663-70.

17. Khan MT, Nieuwdorp M, Backhed F. Microbial modulation of insulin sensitivity. Cell Metab. 2014;20(5):753-60.

18. Sharon G, Garg N, Debelius J, Knight R, Dorrestein PC, Mazmanian SK. Specialized metabolites from the microbiome in health and disease. Cell Metab. 2014;20(5):719-30.

19. Human Microbiome Project C. Structure, function and diversity of the healthy human microbiome. Nature. 2012;486(7402):207-14.

20. Cho I, Blaser MJ. The human microbiome: at the interface of health and disease. Nat Rev Genet. 2012;13(4):260-70.

21. Dumas ME, Barton RH, Toye A, Cloarec O, Blancher C, Rothwell A, Fearnside J, Tatoud R, Blanc V, Lindon JC, et al. Metabolic profiling reveals a contribution of gut microbiota to fatty liver phenotype in insulin-resistant mice. Proc Natl Acad Sci U S A. 2006;103(33):12511-6.

22. Turnbaugh PJ, Gordon J. The core gut microbiome, energy balance and obesity. J Physiol. 2009;587(Pt 17):4153-8.

23. Jumpertz R, Le DS, Turnbaugh PJ, Trinidad C, Bogardus C, Gordon Jl, Krakoff J. Energy-balance studies reveal associations between gut microbes, caloric load, and nutrient absorption in humans. Am J Clin Nutr. 2011:94(1):58-65.

24. Nicholson JK, Holmes E, Kinross J, Burcelin R, Gibson G, Jia W, Pettersson S. Host-gut microbiota metabolic interactions. Science. 2012;336(6086):1262-7.

25. Turnbaugh PJ, Ley RE, Mahowald MA, Magrini V, Mardis ER, Gordon JI. An obesity-associated gut microbiome with increased capacity for energy harvest. Nature. 2006;444(7122):1027-31.

26. Vrieze A, Van Nood E, Holleman F, Salojarvi J, Kootte RS, Bartelsman JF, Dallinga-Thie GM, Ackermans MT, Serlie MJ, Oozeer R, et al. Transfer of intestinal microbiota from lean donors increases insulin sensitivity in individuals with metabolic syndrome. Gastroenterology. 2012;143(4):913-6.

27. Ridaura VK, Faith JJ, Rey FE, Cheng J, Duncan AE, Kau AL, Griffin NW, Lombard V, Henrissat B, Bain JR, et al. Gut microbiota from twins discordant for obesity modulate metabolism in mice. Science. 2013; 341(6150):1079-89.

28. Wikoff WR, Anfora AT, Liu J, Schultz PG, Lesley SA, Peters EC, Siuzdak G. Metabolomics analysis reveals large effects of gut microflora on mammalian blood metabolites. Proc Natl Acad Sci U S A. 2009;106(10):3698-703.

29. Tremaroli $V$, Backhed $F$. Functional interactions between the gut microbiota and host metabolism. Nature. 2012;489(7415):242-9. 
30. Mazmanian SK, Round JL, Kasper DL. A microbial symbiosis factor prevents intestinal inflammatory disease. Nature. 2008;453(7195):620-5.

31. Lathrop SK, Bloom SM, Rao SM, Nutsch K, Lio CW, Santacruz N, Peterson DA, Stappenbeck TS, Hsieh CS. Peripheral education of the immune system by colonic commensal microbiota. Nature. 2011;478(7368):250-4.

32. Cerf-Bensussan N, Gaboriau-Routhiau V. The immune system and the gut microbiota: friends or foes? Nat Rev Immunol. 2010;10(10):735-44.

33. Shulzhenko N, Morgun A, Hsiao W, Battle M, Yao M, Gavrilova O, Orandle M, Mayer L, Macpherson AJ, McCoy KD, et al. Crosstalk between B lymphocytes, microbiota and the intestinal epithelium governs immunity versus metabolism in the gut. Nat Med. 2011;17(12):1585-93.

34. Ivanov II, Atarashi K, Manel N, Brodie EL, Shima T, Karaoz U, Wei D, Goldfarb KC, Santee CA, Lynch SV, et al. Induction of intestinal Th17 cells by segmented filamentous bacteria. Cell. 2009;139(3):485-98.

35. Semenkovich NP, Planer JD, Ahern PP, Griffin NW, Lin CY, Gordon JI. Impact of the gut microbiota on enhancer accessibility in gut intraepithelial lymphocytes. Proc Natl Acad Sci U S A. 2016;113(51):14805-10.

36. Geva-Zatorsky N, Sefik E, Kua L, Pasman L, Tan TG, Ortiz-Lopez A, Yanortsang TB, Yang L, Jupp R, Mathis D, et al. Mining the Human Gut Microbiota for Immunomodulatory Organisms. Cell. 2017;168(5):928-43.

37. Gomez de Aguero M, Ganal-Vonarburg SC, Fuhrer T, Rupp S, Uchimura Y, Li $H$, Steinert A, Heikenwalder M, Hapfelmeier S, Sauer U, et al. The maternal microbiota drives early postnatal innate immune development. Science. 2016;351(6279):1296-302.

38. Fung TC, Olson CA, Hsiao EY. Interactions between the microbiota, immune and nervous systems in health and disease. Nat Neurosci. 2017;20(2):145-55.

39. Macpherson AJ, Harris NL. Interactions between commensal intestinal bacteria and the immune system. Nat Rev Immunol. 2004;4(6):478-85.

40. Hooper LV, Littman DR, Macpherson AJ. Interactions between the microbiota and the immune system. Science. 2012;336(6086):1268-73.

41. Bauer $H$, Horowitz RE, Levenson SM, Popper $H$. The response of the lymphatic tissue to the microbial flora. Studies on germfree mice. Am J Pathol. 1963;42:471-83

42. Breitbart M, Hewson I, Felts B, Mahaffy JM, Nulton J, Salamon P, Rohwer F. Metagenomic analyses of an uncultured viral community from human feces. J Bacteriol. 2003:185(20):6220-3.

43. Ghannoum MA, Jurevic RJ, Mukherjee PK, Cui F, Sikaroodi M, Naqvi A, Gillevet PM. Characterization of the oral fungal microbiome (mycobiome) in healthy individuals. PLoS Pathog. 2010;6(1):e1000713.

44. Whitman WB, Coleman DC, Wiebe WJ. Prokaryotes: the unseen majority. Proc Natl Acad Sci U S A. 1998;95(12):6578-83.

45. Reyes A, Haynes M, Hanson N, Angly FE, Heath AC, Rohwer F, Gordon Jl. Viruses in the faecal microbiota of monozygotic twins and their mothers. Nature. 2010;466(7304):334-8.

46. Blaser MJ, Kirschner D. The equilibria that allow bacterial persistence in human hosts. Nature. 2007:449(7164):843-9.

47. Li J, Jia H, Cai X, Zhong H, Feng Q, Sunagawa S, Arumugam M, Kultima JR, Prifti E, Nielsen T, et al. An integrated catalog of reference genes in the human gut microbiome. Nat Biotechnol. 2014;32(8):834-41.

48. Backhed F, Ley RE, Sonnenburg JL, Peterson DA, Gordon JI. Host-bacterial mutualism in the human intestine. Science. 2005;307(5717):1915-20.

49. David LA, Maurice CF, Carmody RN, Gootenberg DB, Button JE, Wolfe BE, Ling AV, Devlin AS, Varma Y, Fischbach MA, et al. Diet rapidly and reproducibly alters the human gut microbiome. Nature. 2014;505(7484): 559-63.

50. Turnbaugh PJ, Ridaura VK, Faith JJ, Rey FE, Knight R, Gordon Jl. The effect of diet on the human gut microbiome: a metagenomic analysis in humanized gnotobiotic mice. Sci Transl Med. 2009;1(6):6ra14.

51. Wu GD, Chen J, Hoffmann C, Bittinger K, Chen YY, Keilbaugh SA, Bewtra M, Knights D, Walters WA, Knight R, et al. Linking long-term dietary patterns with gut microbial enterotypes. Science. 2011;334(6052):105-8.

52. Cotillard A, Kennedy SP, Kong LC, Prifti E, Pons N, Le Chatelier E, Almeida M, Quinquis B, Levenez F, Galleron N, et al. Dietary intervention impact on gut microbial gene richness. Nature. 2013;500(7464):585-8.

53. Conlon MA, Bird AR. The impact of diet and lifestyle on gut microbiota and human health. Nutrients. 2014;7(1):17-44.

54. Zarrinpar A, Chaix A, Yooseph S, Panda S. Diet and feeding pattern affect the diurnal dynamics of the gut microbiome. Cell Metab. 2014;20(6):1006-17.

55. Shoaie $S$, Ghaffari $P$, Kovatcheva-Datchary $P$, Mardinoglu A, Sen P, Pujos-Guillot E, de Wouters T, Juste C, Rizkalla S, Chilloux J, et al. Quantifying Diet-Induced Metabolic Changes of the Human Gut Microbiome. Cell Metab. 2015;22(2):320-31.
56. Muegge BD, Kuczynski J, Knights D, Clemente JC, Gonzalez A, Fontana L, Henrissat B, Knight R, Gordon Jl. Diet drives convergence in gut microbiome functions across mammalian phylogeny and within humans. Science. 2011:332(6032):970-4.

57. Ussar S, Griffin NW, Bezy O, Fujisaka S, Vienberg S, Softic S, Deng L, Bry L, Gordon JI, Kahn CR. Interactions between Gut Microbiota, Host Genetics and Diet Modulate the Predisposition to Obesity and Metabolic Syndrome. Cell Metab. 2015;22(3):516-30.

58. Sherman $\mathrm{H}$, Chapnik N, Froy O. Albumin and amino acids upregulate the expression of human beta-defensin 1. Mol Immunol. 2006:43(10):1617-23.

59. Ren M, Zhang S, Liu X, Li S, Mao X, Zeng X, Qiao S. Different Lipopolysaccharide Branched-Chain Amino Acids Modulate Porcine Intestinal Endogenous beta-Defensin Expression through the Sirt1/ERK/90RSK Pathway. J Agric Food Chem. 2016;64(17):3371-9.

60. Yang Z, Huang S, Zou D, Dong D, He X, Liu N, Liu W, Huang L. Metabolic shifts and structural changes in the gut microbiota upon branched-chain amino acid supplementation in middle-aged mice. Amino Acids. 2016; 48(12):2731-45

61. Waterlow JC, Golden MH, Garlick PJ. Protein turnover in man measured with 15N: comparison of end products and dose regimes. Am J Phys. 1978:235(2):E165-74.

62. De Bandt JP, Cynober L. Therapeutic use of branched-chain amino acids in burn, trauma, and sepsis. J Nutr. 2006;136(1 Suppl):308S-13S.

63. Broer S. Amino acid transport across mammalian intestinal and renal epithelia. Physiol Rev. 2008;88(1):249-86.

64. Han JM, Jeong SJ, Park MC, Kim G, Kwon NH, Kim HK, Ha SH, Ryu SH, Kim S. Leucyl-tRNA synthetase is an intracellular leucine sensor for the mTORC1-signaling pathway. Cell. 2012;149(2):410-24.

65. Wolfson RL, Chantranupong L, Saxton RA, Shen K, Scaria SM, Cantor JR, Sabatini DM. Sestrin2 is a leucine sensor for the mTORC1 pathway. Science. 2016;351(6268):43-8.

66. Flati V, Caliaro F, Speca S, Corsetti G, Cardile A, Nisoli E, Bottinelli R. G DA: Essential amino acids improve insulin activation of AKT/MTOR signaling in soleus muscle of aged rats. Int J Immunopathol Pharmacol. 2010;23(1):81-9.

67. Pansarasa O, Flati V, Corsetti G, Brocca L, Pasini E, D'Antona G. Oral amino acid supplementation counteracts age-induced sarcopenia in elderly rats. Am J Cardiol. 2008;101(11A):35E-41E.

68. Nair KS, Woolf PD, Welle SL, Matthews DE. Leucine, glucose, and energy metabolism after 3 days of fasting in healthy human subjects. Am J Clin Nutr. 1987:46(4):557-62.

69. Lips MA, Van Klinken JB, van Harmelen V, Dharuri HK, t Hoen PA, Laros JF, van Ommen GJ, Janssen IM, Van Ramshorst B, Van Wagensveld BA, et al. Roux-en-Y gastric bypass surgery, but not calorie restriction, reduces plasma branched-chain amino acids in obese women independent of weight loss or the presence of type 2 diabetes. Diabetes Care. 2014;37(12):3150-6.

70. Toshima T, Shirabe K, Kurihara T, Itoh S, Harimoto N, Ikegami T, Yoshizumi T, Kawanaka H, Ikeda T, Maehara Y. Profile of plasma amino acids values as a predictor of sepsis in patients following living donor liver transplantation: Special reference to sarcopenia and postoperative early nutrition. Hepatol Res. 2015;45(12):1170-7.

71. Liu Y, Xiao X, Qin DP, Tan RS, Zhong XS, Zhou DY, Liu Y, Xiong X, Zheng YY. Comparison of intradialytic parenteral nutrition with glucose or amino acid mixtures in maintenance hemodialysis patients. Nutrients. 2016:8(6). PMID: 27271658; PMCID: PMC4924157. doi:10.3390/nu8060220.

72. Yuan HX, Xiong $Y$, Guan KL. Nutrient sensing, metabolism, and cell growth control. Mol Cell. 2013;49(3):379-87.

73. Harris RA, Joshi M, Jeoung NH, Obayashi M. Overview of the molecular and biochemical basis of branched-chain amino acid catabolism. J Nutr. 2005; 135(6 Suppl):1527S-30S.

74. Mitch WE, Walser M, Steinman TI, Hill S, Zeger S, Tungsanga K. The effect of a keto acid-amino acid supplement to a restricted diet on the progression of chronic renal failure. N Engl J Med. 1984;311(10):623-9.

75. Jones R, Dalton N, Turner C, Start K, Haycock G, Chantler C. Oral essential aminoacid and ketoacid supplements in children with chronic renal failure. Kidney Int. 1983;24(1):95-103

76. Cano NJ, Fouque D, Leverve XM. Application of branched-chain amino acids in human pathological states: renal failure. J Nutr. 2006;136(1 Suppl):299S-307S

77. Kawaguchi T, Izumi N, Charlton MR, Sata M. Branched-chain amino acids as pharmacological nutrients in chronic liver disease. Hepatology. 2011:54(3): 1063-70. 
78. Steigmann F, Szanto PB, Poulos A, Lim PE, Dubin A. Significance of serum aminograms in diagnosis and prognosis of liver diseases. J Clin Gastroenterol. 1984;6(5):453-60.

79. Tsukishiro T, Shimizu Y, Higuchi K, Watanabe A. Effect of branched-chain amino acids on the composition and cytolytic activity of liver-associated lymphocytes in rats. J Gastroenterol Hepatol. 2000;15(8):849-59.

80. Lesourd B. Protein undernutrition as the major cause of decreased immune function in the elderly: clinical and functional implications. Nutr Rev. 1995; 53(4 Pt 2):S86-91. discussion S92-84

81. Nakamura I, Ochiai K, Imawari M. Phagocytic function of neutrophils of patients with decompensated liver cirrhosis is restored by oral supplementation of branched-chain amino acids. Hepatol Res. 2004;29(4):207-11.

82. Nakamura I, Ochiai K, Imai Y, Moriyasu F, Imawari M. Restoration of innate host defense responses by oral supplementation of branchedchain amino acids in decompensated cirrhotic patients. Hepatol Res. 2007;37(12):1062-7.

83. Bolasco P, Caria S, Cupisti A, Secci R, Saverio Dioguardi FS. A novel amino acids oral supplementation in hemodialysis patients: a pilot study. Ren Fail. 2011;33(1):1-5

84. Lian K, Du C, Liu Y, Zhu D, Yan W, Zhang H, Hong Z, Liu P, Zhang L, Pei $\mathrm{H}$, et al. Impaired adiponectin signaling contributes to disturbed catabolism of branched-chain amino acids in diabetic mice. Diabetes. 2015;64(1):49-59.

85. Tremblay F, Marette A. Amino acid and insulin signaling via the mTOR/p70 S6 kinase pathway. A negative feedback mechanism leading to insulin resistance in skeletal muscle cells. J Biol Chem. 2001;276(41):38052-60.

86. Newgard CB, An J, Bain JR, Muehlbauer MJ, Stevens RD, Lien LF, Haqq AM, Shah SH, Arlotto M, Slentz CA, et al. A branched-chain amino acid-related metabolic signature that differentiates obese and lean humans and contributes to insulin resistance. Cell Metab. 2009:9(4):311-26.

87. Lee CC, Watkins SM, Lorenzo C, Wagenknecht LE, Il'yasova D, Chen YD, Haffner SM, Hanley AJ. Branched-Chain Amino Acids and Insulin Metabolism: The Insulin Resistance Atherosclerosis Study (IRAS). Diabetes Care. 2016;39(4):582-8.

88. Yoon MS. The emerging role of branched-chain amino acids in insulin resistance and metabolism. Nutrients. 2016;8(7). PMID: 27376324; PMCID: PMC4963881. doi:10.3390/nu8070405.

89. Jang C, Oh SF, Wada S, Rowe GC, Liu L, Chan MC, Rhee J, Hoshino A, Kim B, Ibrahim A, et al. A branched-chain amino acid metabolite drives vascular fatty acid transport and causes insulin resistance. Nat Med. 2016;22(4):421-6

90. Zemel MB, Bruckbauer A. Effects of a leucine and pyridoxine-containing nutraceutical on fat oxidation, and oxidative and inflammatory stress in overweight and obese subjects. Nutrients. 2012;4(6):529-41.

91. Qin LQ, Xun P, Bujnowski D, Daviglus ML, Van Horn L, Stamler J, He K, Group ICR. Higher branched-chain amino acid intake is associated with a lower prevalence of being overweight or obese in middle-aged East Asian and Western adults. J Nutr. 2011;141(2):249-54.

92. Solerte SB, Fioravanti M, Locatelli E, Bonacasa R, Zamboni M, Basso C, Mazzoleni A, Mansi V, Geroutis N, Gazzaruso C. Improvement of blood glucose control and insulin sensitivity during a long-term (60 weeks) randomized study with amino acid dietary supplements in elderly subjects with type 2 diabetes mellitus. Am J Cardiol. 2008;101(11A):82E-8E.

93. Kawaguchi T, Nagao Y, Matsuoka H, Ide T, Sata M. Branched-chain amino acid-enriched supplementation improves insulin resistance in patients with chronic liver disease. Int J Mol Med. 2008;22(1):105-12.

94. Eley HL, Russell ST, Tisdale MJ. Effect of branched-chain amino acids on muscle atrophy in cancer cachexia. Biochem J. 2007;407(1):113-20.

95. Corsetti G, Stacchiotti A, DA G, Nisoli E, Dioguardi FS, Rezzani R. Supplementation with essential amino acids in middle age maintains the health of rat kidney. Int J Immunopathol Pharmacol. 2010;23(2):523-33.

96. Pellegrino MA, Patrini C, Pasini E, Brocca L, Flati V, Corsetti G, D'Antona $\mathrm{G}$. Amino acid supplementation counteracts metabolic and functional damage in the diabetic rat heart. Am J Cardiol. 2008;101(11A):49E-56E.

97. Corsetti G, D'Antona G, Dioguardi FS, Rezzani R. Topical application of dressing with amino acids improves cutaneous wound healing in aged rats. Acta Histochem. 2010;112(5):497-507.

98. Said HM. Intestinal absorption of water-soluble vitamins in health and disease. Biochem J. 2011;437(3):357-72.

99. Martens $\mathrm{JH}$, Barg H, Warren MJ, Jahn D. Microbial production of vitamin B12. Appl Microbiol Biotechnol. 2002;58(3):275-85.
100. Komaroff AL. The Microbiome and Risk for Obesity and Diabetes. JAMA. 2017:317(4):355-6.

101. Saad MJ, Santos A, Prada PO. Linking Gut Microbiota and Inflammation to Obesity and Insulin Resistance. Physiology (Bethesda). 2016:31(4):283-93.

102. Cox AJ, West NP, Cripps AW. Obesity, inflammation, and the gut microbiota. Lancet Diabetes Endocrinol. 2015;3(3):207-15.

103. Cani PD, Bibiloni R, Knauf C, Waget A, Neyrinck AM, Delzenne NM, Burcelin R. Changes in gut microbiota control metabolic endotoxemia-induced inflammation in high-fat diet-induced obesity and diabetes in mice. Diabetes. 2008;57(6):1470-81.

104. de La Serre CB, Ellis CL, Lee J, Hartman AL, Rutledge JC, Raybould HE. Propensity to high-fat diet-induced obesity in rats is associated with changes in the gut microbiota and gut inflammation. Am J Physiol Gastrointest Liver Physiol. 2010;299(2):G440-8.

105. Caesar R, Fak F, Backhed F. Effects of gut microbiota on obesity and atherosclerosis via modulation of inflammation and lipid metabolism. J Intern Med. 2010;268(4):320-8.

106. Caesar R, Tremaroli V, Kovatcheva-Datchary P, Cani PD, Backhed F. Crosstalk between Gut Microbiota and Dietary Lipids Aggravates WAT Inflammation through TLR Signaling. Cell Metab. 2015;22(4):658-68.

107. Samuel BS, Shaito A, Motoike T, Rey FE, Backhed F, Manchester JK, Hammer RE Williams SC, Crowley J, Yanagisawa M, et al. Effects of the gut microbiota on host adiposity are modulated by the short-chain fatty-acid binding $\mathrm{G}$ protein-coupled receptor, Gpr41. Proc Natl Acad Sci U S A. 2008; 105(43):16767-72

108. Brown AJ, Goldsworthy SM, Barnes AA, Eilert MM, Tcheang L, Daniels D, Muir Al, Wigglesworth MJ, Kinghorn I, Fraser NJ, et al. The Orphan G protein-coupled receptors GPR41 and GPR43 are activated by propionate and other short chain carboxylic acids. J Biol Chem. 2003;278(13):11312-9.

109. Wichmann A, Allahyar A, Greiner TU, Plovier H, Lunden GO, Larsson T, Drucker DJ, Delzenne NM, Cani PD, Backhed F. Microbial modulation of energy availability in the colon regulates intestinal transit. Cell Host Microbe. 2013;14(5):582-90.

110. Yadav H, Lee JH, Lloyd J, Walter P, Rane SG. Beneficial metabolic effects of a probiotic via butyrate-induced GLP-1 hormone secretion. J Biol Chem. 2013; 288(35):25088-97.

111. Tolhurst G, Heffron H, Lam YS, Parker HE, Habib AM, Diakogiannaki E, Cameron J, Grosse J, Reimann F, Gribble FM. Short-chain fatty acids stimulate glucagon-like peptide-1 secretion via the G-protein-coupled receptor FFAR2. Diabetes. 2012; 61(2):364-71.

112. Brubaker PL. Minireview: update on incretin biology: focus on glucagon-like peptide-1. Endocrinology. 2010;151(5):1984-9.

113. Donohoe DR, Garge N, Zhang X, Sun W, O'Connell TM, Bunger MK, Bultman SJ. The microbiome and butyrate regulate energy metabolism and autophagy in the mammalian colon. Cell Metab. 2011;13(5):517-26.

114. Fernandes J, Su W, Rahat-Rozenbloom S, Wolever TM, Comelli EM. Adiposity, gut microbiota and faecal short chain fatty acids are linked in adult humans. Nutr Diabetes. 2014:4:e121.

115. Smith PM, Howitt MR, Panikov N, Michaud M, Gallini CA, Bohlooly YM, Glickman JN, Garrett WS. The microbial metabolites, short-chain fatty acids, regulate colonic Treg cell homeostasis. Science. 2013;341(6145): 569-73.

116. Curi R, Bond JA, Calder PC, Newsholme EA. Propionate regulates lymphocyte proliferation and metabolism. Gen Pharmacol. 1993:24(3):591-7.

117. Farningham DA, Whyte CC. The role of propionate and acetate in the control of food intake in sheep. Br J Nutr. 1993;70(1):37-46.

118. Kawamata K, Hayashi H, Suzuki Y. Propionate absorption associated with bicarbonate secretion in vitro in the mouse cecum. Pflugers Arch. 2007; 454(2):253-62.

119. Perry RJ, Peng L, Barry NA, Cline GW, Zhang D, Cardone RL, Petersen KF, Kibbey RG, Goodman AL, Shulman GI. Acetate mediates a microbiomebrain-beta-cell axis to promote metabolic syndrome. Nature. 2016; 534(7606):213-7.

120. Mueller S, Saunier K, Hanisch C, Norin E, Alm L, Midtvedt T, Cresci A, Silvi $\mathrm{S}$, Orpianesi C, Verdenelli MC, et al. Differences in fecal microbiota in different European study populations in relation to age, gender, and country: a cross-sectional study. Appl Environ Microbiol. 2006;72(2):1027-33.

121. Charbonneau MR, Blanton LV, DiGiulio DB, Relman DA, Lebrilla CB, Mills DA, Gordon J. A microbial perspective of human developmental biology. Nature. 2016;535(7610):48-55.

122. Sharon I, Morowitz MJ, Thomas BC, Costello EK, Relman DA, Banfield JF. Time series community genomics analysis reveals rapid shifts in bacterial 
species, strains, and phage during infant gut colonization. Genome Res. 2013;23(1):111-20.

123. Costello EK, Lauber CL, Hamady M, Fierer N, Gordon JI, Knight R. Bacterial community variation in human body habitats across space and time. Science. 2009;326(5960):1694-7.

124. Lakshminarayanan B, Stanton C, O'Toole PW, Ross RP. Compositional dynamics of the human intestinal microbiota with aging: implications for health. J Nutr Health Aging. 2014;18(9):773-86.

125. OToole PW, Jeffery IB. Gut microbiota and aging. Science. 2015;350(6265):1214-5.

126. Lozupone CA, Stombaugh Jl, Gordon JI, Jansson JK, Knight R. Diversity, stability and resilience of the human gut microbiota. Nature. 2012:489(7415):220-30.

127. Vaiserman AM, Koliada AK, Marotta F. Gut microbiota: A player in aging and a target for anti-aging intervention. Ageing Res Rev. 2017;35:36-45.

128. Meehan CJ, Langille MG, Beiko RG. Frailty and the Microbiome. Interdiscip Top Gerontol Geriatr. 2015;41:54-65.

129. Friedland RP. Mechanisms of molecular mimicry involving the microbiota in neurodegeneration. J Alzheimers Dis. 2015;45(2):349-62.

130. Magnusson KR, Hauck L, Jeffrey BM, Elias V, Humphrey A, Nath R, Perrone A, Bermudez LE. Relationships between diet-related changes in the gut microbiome and cognitive flexibility. Neuroscience. 2015;300:128-40.

131. Paun A, Danska JS. Modulation of type 1 and type 2 diabetes risk by the intestinal microbiome. Pediatr Diabetes. 2016:17(7):469-77.

132. Sanduzzi Zamparelli M, Compare D, Coccoli P, Rocco A, Nardone OM, Marrone G, Gasbarrini A, Grieco A, Nardone G, Miele L. The metabolic role of gut microbiota in the development of nonalcoholic fatty liver disease and cardiovascular disease. Int J Mol Sci. 2016;17(8). PMID: 27483246; PMCID: PMC5000623; doi:10.3390/ijms17081225.

133. Jonsson AL, Backhed F. Role of gut microbiota in atherosclerosis. Nat Rev Cardiol. 2017;14(2):79-87.

134. Chevalier C, Stojanovic O, Colin DJ, Suarez-Zamorano N, Tarallo V, VeyratDurebex C, Rigo D, Fabbiano S, Stevanovic A, Hagemann S, et al. Gut Microbiota Orchestrates Energy Homeostasis during Cold. Cell. 2015; 163(6):1360-74.

135. Minot S, Sinha R, Chen J, Li H, Keilbaugh SA, Wu GD, Lewis JD, Bushman FD. The human gut virome: inter-individual variation and dynamic response to diet. Genome Res. 2011;21(10):1616-25.

136. Le Chatelier E, Nielsen T, Qin J, Prifti E, Hildebrand F, Falony G, Almeida M, Arumugam M, Batto JM, Kennedy S, et al. Richness of human gut microbiome correlates with metabolic markers. Nature. 2013;500(7464):541-6.

137. Ley RE, Turnbaugh PJ, Klein S, Gordon Jl. Microbial ecology: human gut microbes associated with obesity. Nature. 2006;444(7122):1022-3.

138. Henao-Mejia J, Elinav E, Jin C, Hao L, Mehal WZ, Strowig T, Thaiss CA, Kau AL, Eisenbarth SC, Jurczak MJ, et al. Inflammasome-mediated dysbiosis regulates progression of NAFLD and obesity. Nature. 2012:482(7384):179-85.

139. Upadhyay V, Poroyko V, Kim TJ, Devkota S, Fu S, Liu D, Tumanov AV, Koroleva EP, Deng L, Nagler C, et al. Lymphotoxin regulates commensal responses to enable diet-induced obesity. Nat Immunol. 2012;13(10):947-53.

140. Keeney KM, Yurist-Doutsch S, Arrieta MC, Finlay BB. Effects of antibiotics on human microbiota and subsequent disease. Annu Rev Microbiol. 2014;68:217-35

141. Le Roy T, Llopis M, Lepage P, Bruneau A, Rabot S, Bevilacqua C, Martin P, Philippe C, Walker F, Bado A, et al. Intestinal microbiota determines development of non-alcoholic fatty liver disease in mice. Gut. 2013:62(12):1787-94.

142. Mozes S, Bujnakova D, Sefcikova Z, Kmet V. Developmental changes of gut microflora and enzyme activity in rat pups exposed to fat-rich diet. Obesity (Silver Spring). 2008;16(12):2610-5.

143. Backhed F, Ding H, Wang T, Hooper LV, Koh GY, Nagy A, Semenkovich CF, Gordon JI. The gut microbiota as an environmental factor that regulates fat storage. Proc Natl Acad Sci U S A. 2004;101(44):15718-23.

144. Wang Z, Klipfell E, Bennett BJ, Koeth R, Levison BS, Dugar B, Feldstein AE, Britt EB, Fu X, Chung YM, et al. Gut flora metabolism of phosphatidylcholine promotes cardiovascular disease. Nature. 2011:472(7341):57-63.

145. Devkota S, Wang Y, Musch MW, Leone V, Fehlner-Peach H, Nadimpalli A, Antonopoulos DA, Jabri B, Chang EB. Dietary-fat-induced taurocholic acid promotes pathobiont expansion and colitis in II10-/- mice. Nature. 2012; 487(7405):104-8

146. Cammarota G, laniro G, Tilg H, Rajilic-Stojanovic M, Kump P, Satokari R, Sokol H, Arkkila P, Pintus C, Hart A, et al. European consensus conference on faecal microbiota transplantation in clinical practice. Gut. 2017;66(4):569-80.
147. Cummings JH, Macfarlane GT. Colonic microflora: nutrition and health Nutrition. 1997;13(5):476-8.

148. Schaible TD, Harris RA, Dowd SE, Smith CW, Kellermayer R. Maternal methyldonor supplementation induces prolonged murine offspring colitis susceptibility in association with mucosal epigenetic and microbiomic changes. Hum Mol Genet. 2011;20(9):1687-96.

149. Chen Q, Reimer RA. Dairy protein and leucine alter GLP-1 release and mRNA of genes involved in intestinal lipid metabolism in vitro. Nutrition. 2009;25(3):340-9.

150. Gojda J, Strakova R, Plihalova A, Tuma P, Potockova J, Polak J, Andel M. Increased Incretin But Not Insulin Response after Oral versus Intravenous Branched Chain Amino Acids. Ann Nutr Metab. 2017;70(4):293-302.

151. Steinert RE, Landrock MF, Ullrich SS, Standfield S, Otto B, Horowitz M, Feinle-Bisset $C$. Effects of intraduodenal infusion of the branched-chain amino acid leucine on ad libitum eating, gut motor and hormone functions, and glycemia in healthy men. Am J Clin Nutr. 2015;102(4):820-7.

152. Jakobsson HE, Rodriguez-Pineiro AM, Schutte A, Ermund A, Boysen P, Bemark M, Sommer F, Backhed F, Hansson GC, Johansson ME. The composition of the gut microbiota shapes the colon mucus barrier. EMBO Rep. 2015;16(2):164-77.

153. Liu R, Hong J, Xu X, Feng Q, Zhang D, Gu Y, Shi J, Zhao S, Liu W, Wang X, et al. Gut microbiome and serum metabolome alterations in obesity and after weight-loss intervention. Nat Med. 2017;23(7):859-68.

154. Thomas D, Surdin-Kerjan Y. Metabolism of sulfur amino acids in Saccharomyces cerevisiae. Microbiol Mol Biol Rev. 1997;61(4):503-32.

155. Kohlhaw GB. Leucine biosynthesis in fungi: entering metabolism through the back door. Microbiol Mol Biol Rev. 2003;67(1):1-15.

156. Micha R, Penalvo JL, Cudhea F, Imamura F, Rehm CD, Mozaffarian D. Association Between Dietary Factors and Mortality From Heart Disease, Stroke, and Type 2 Diabetes in the United States. JAMA. 2017:317(9):912-24.

157. Passarino G, De Rango F, Montesanto A. Human longevity: Genetics or Lifestyle? It takes two to tango. Immun Ageing. 2016;13:12.

158. Konturek PC, Haziri D, Brzozowski T, Hess T, Heyman S, Kwiecien S, Konturek $\mathrm{SJ}$, Koziel J. Emerging role of fecal microbiota therapy in the treatment of gastrointestinal and extra-gastrointestinal diseases. J Physiol Pharmacol. 2015:66(4):483-91.

159. McAllan L, Cotter PD, Roche HM, Korpela R, Nilaweera KN. Impact of leucine on energy balance. J Physiol Biochem. 2013;69(1):155-63.

160. Chu DM, Ma J, Prince AL, Antony KM, Seferovic MD, Aagaard KM. Maturation of the infant microbiome community structure and function across multiple body sites and in relation to mode of delivery. Nat Med. 2017;23(3):314-26

161. McGuire MK, McGuire MA. Human milk: mother nature's prototypical probiotic food? Adv Nutr. 2015;6(1):112-23.

162. Fukuda S, Toh H, Hase K, Oshima K, Nakanishi Y, Yoshimura K, Tobe T, Clarke $J M$, Topping DL, Suzuki T, et al. Bifidobacteria can protect from enteropathogenic infection through production of acetate. Nature. 2011:469(7331):543-7

163. Huda MN, Lewis Z, Kalanetra KM, Rashid M, Ahmad SM, Raqib R, Qadri F, Underwood MA, Mills DA, Stephensen CB. Stool microbiota and vaccine responses of infants. Pediatrics. 2014;134(2):e362-72.

164. Sugahara H, Odamaki T, Hashikura N, Abe F, Xiao JZ. Differences in folate production by bifidobacteria of different origins. Biosci Microbiota Food Health. 2015;34(4):87-93.

165. Laukens D, Brinkman BM, Raes J, De Vos M, Vandenabeele P. Heterogeneity of the gut microbiome in mice: guidelines for optimizing experimental design. FEMS Microbiol Rev. 2016:40(1):117-32.

166. Markle JG, Frank DN, Mortin-Toth S, Robertson CE, Feazel LM, Rolle-Kampczyk U, von Bergen M, McCoy KD, Macpherson AJ, Danska JS. Sex differences in the gut microbiome drive hormone-dependent regulation of autoimmunity. Science. 2013;339(6123):1084-8.

167. Bercik P, Denou E, Collins J, Jackson W, Lu J, Jury J, Deng Y, Blennerhassett $P$, Macri J, McCoy KD, et al. The intestinal microbiota affect central levels of brain-derived neurotropic factor and behavior in mice. Gastroenterology. 2011;141(2):599-609.

168. Diaz Heijtz R, Wang S, Anuar F, Qian Y, Bjorkholm B, Samuelsson A, Hibberd ML, Forssberg H, Pettersson S. Normal gut microbiota modulates brain development and behavior. Proc Natl Acad Sci U S A. 2011:108(7):3047-52.

169. Sudo N, Chida Y, Aiba Y, Sonoda J, Oyama N, Yu XN, Kubo C, Koga Y. Postnatal microbial colonization programs the hypothalamic-pituitaryadrenal system for stress response in mice. J Physiol. 2004;558(Pt 1):263-75. 
170. Schroeder BO, Backhed F. Signals from the gut microbiota to distant organs in physiology and disease. Nat Med. 2016;22(10):1079-89.

171. Mayer EA, Knight R, Mazmanian SK, Cryan JF, Tillisch K. Gut microbes and the brain: paradigm shift in neuroscience. J Neurosci. 2014;34(46):15490-6.

172. Sharon G, Sampson TR, Geschwind DH, Mazmanian SK. The Central Nervous System and the Gut Microbiome. Cell. 2016;167(4):915-32.

173. Fernstrom JD. Branched-chain amino acids and brain function. J Nutr. 2005; 135(6 Suppl):1539S-46S.

174. Hutson SM, Sweatt AJ, Lanoue KF. Branched-chain amino acid metabolism: implications for establishing safe intakes. J Nutr. 2005;135(6 Suppl):1557S-64S.

175. Scarna A, Gijsman HJ, McTavish SF, Harmer CJ, Cowen PJ, Goodwin GM. Effects of a branched-chain amino acid drink in mania. Br J Psychiatry. 2003; 182:210-3.

176. Sampson TR, Debelius JW, Thron T, Janssen S, Shastri GG, Ilhan ZE, Challis C, Schretter CE, Rocha S, Gradinaru V, et al. Gut Microbiota Regulate Motor Deficits and Neuroinflammation in a Model of Parkinson's Disease. Cell. 2016;167(6):1469-80.

177. Malkki H. Stroke: Gut microbiota influence stroke recovery in mice. Nat Rev Neurol. 2016;12(5):252.

178. Benakis C, Brea D, Caballero S, Faraco G, Moore J, Murphy M, Sita G, Racchumi G, Ling L, Pamer EG, et al. Commensal microbiota affects ischemic stroke outcome by regulating intestinal $\Gamma \Delta \mathrm{T}$ cells. Nat Med. 2016;22(5):516-23

\section{Submit your next manuscript to BioMed Central} and we will help you at every step:

- We accept pre-submission inquiries

- Our selector tool helps you to find the most relevant journal

- We provide round the clock customer support

- Convenient online submission

- Thorough peer review

- Inclusion in PubMed and all major indexing services

- Maximum visibility for your research

Submit your manuscript at www.biomedcentral.com/submit 